\title{
O Anticristo e sua liga
}

\author{
The Antichrist and his league
}

\author{
Cláudio Vianney Malzoni
}

\section{Resumo}

O presente texto se propõe a abordar o uso da palavra anticristo nas cartas joaninas, seu lugar na escatologia dos escritos joaninos e as semelhanças das atestações nas quais ocorre essa palavra com outras personagens do Novo Testamento: o pseudocristo mencionado em discurso direto de Jesus, presente no Evangelho segundo Marcos e no Evangelho segundo Mateus, o pseudoprofeta no Apocalipse e na Segunda Carta de Pedro, o filho da iniquidade na Segunda Carta aos Tessalonicenses. A metodologia utilizada foi a do levantamento das atestações das palavras chave na concordância do Novo Testamento grego, a consulta aos dicionários e o diálogo com biblistas que trataram dos diversos temas que se entrecruzam nesta pesquisa. Como resultado, propõe-se a possibilidade da distinção do uso da palavra anticristo no singular e no plural nas cartas joaninas: no singular remetendo a uma figura extraeclesial, no plural remetendo a uma realidade que tem sua origem no âmbito intraeclesial.

Palavras-chave: Anticristo. Primeira Carta de João. Segunda Carta de João. Escatologia bíblica.

\begin{abstract}
This text proposes to approach the use of the word antichrist in the Johannine letters, its place in the eschatology of the Johannine writings and the similarities of the attestations in which this word occurs with other New Testament characters: the pseudo-christ mentioned in a direct discourse of Jesus, present in the Gospel according to Mark and the Gospel according
\end{abstract}


to Matthew, the pseudo-prophet in the Apocalypse and in the Second Letter of Peter, the son of iniquity in the Second Letter to the Thessalonians. The methodology used was the survey of the attestations of the keywords in the concordance of the Greek New Testament, the consultation in the dictionaries and the dialogue with exegetes that dealt with the diverse themes that intersect in this research. As a result, it is proposes the possibility of distinguishing the use of the word antichrist in the singular and the plural in the Johannine letters: in the singular referring to an extra-ecclesial figure, in the plural referring to a reality that has its origin in the intra-ecclesial context.

Keywords: Antichrist. First Letter of John. Second Letter of John. Biblical eschatology.

\section{Introdução}

O mês da Bíblia de 2019 trouxe como tema a Primeira Carta de João, com o lema "Nós amamos porque Deus primeiro nos amou", tomado de 1Jo 4,19. Para essa ocasião, foram elaborados diversos subsídios abordando a Primeira Carta de João, desde o texto base publicado pela CNBB, ${ }^{1}$ aos materiais para os círculos bíblicos e grupos comunitários, e alguns comentários à Carta que, embora simples, não são desprovidos de importância. Esses subsídios, por seu caráter abrangente, não podem abordar todas as questões levantadas pela leitura da Carta.

A Primeira Carta de João é conhecida como um escrito que coloca o amor em primeiro plano. Esse dado não pode ser negado. A simples constatação da frequência de atestações do substantivo agápē, amor, do verbo agapáō, amar, e do adjetivo agapētós, amado, na Carta já o comprova. São 18 atestações do substantivo, 28 atestações do verbo e 6 atestações do adjetivo, para um escrito com apenas cinco capítulos. ${ }^{2}$ Essa prioridade do amor, contudo, não pode impedir de se ver que a Primeira Carta de João é um escrito fortemente polêmico, composto após um conflito intraeclesial que, de tão agudo, resultou

\footnotetext{
${ }^{1}$ MALZONI, C. V.; COMISSÃO EPISCOPAL PASTORAL PARA A ANIMAÇÃO B'BILICA E CATEQUÉTICA DA CNBB. Mês da Bíblia 2019.

${ }^{2}$ As estatísticas de frequência foram tomadas de INSTITUTE FOR NEW TESTAMENT TEXTUAL RESEARCH AND THE COMPUTER CENTER OF MÜNSTER UNIVERSITY, Concordance to the Novum Testamentum Graece of Nestle-Aland, $26^{\text {th }}$ edition, and to the Greek New Testament.
} 
em uma cisão. Aqueles que deixaram a comunidade são chamados pelo autor da Carta de anticristos (1Jo 2,18-19).

O presente texto começa com uma breve explanação das cartas de João, situando-as no conjunto da literatura joanina. Na sequência, trata, especificamente, da palavra anticristo, em suas cinco atestações no Novo Testamento: quatro na Primeira Carta de João e uma na Segunda Carta de João, recorrendo, igualmente, ao significado expresso para essa palavra em alguns dicionários.

O contexto dessas atestações deixa entrever que o autor da Primeira Carta de João vê, na manifestação dos anticristos, um sinal de que "é chegada a última hora" (1 Jo 2,18), situando a questão no horizonte da escatologia. Ora, a escatologia nas cartas joaninas é um tema pouco explicitado, ainda mais quando se compara com o que já se escreveu sobre as perspectivas da escatologia presente e futura no Evangelho segundo João. Esse contexto escatológico no qual se insere a figura do anticristo que, por sua atuação, sinaliza que o fim está próximo, faz lembrar as figuras do pseudocristo, presente no discurso escatológico de Jesus nos evangelhos segundo Marcos e segundo Mateus, do pseudoprofeta do livro do Apocalipse e dos pseudoprofetas da Segunda Carta de Pedro, e a do filho da iniquidade da Segunda Carta aos Tessalonicenses. As semelhanças e diferenças entre essas figuras é o próximo subtema deste texto.

Nas considerações finais, essas figuras serão confrontadas com o esquema escatológico do acirramento do conflito, a última hora, de acordo com o modo de se expressar do autor da Primeira Carta de João, que marca o momento imediatamente anterior ao fim. Tais considerações podem ajudar os cristãos na atualidade a se situar em meio aos conflitos que atingem a sociedade e a Igreja? Essa é a questão que encerra este texto.

\section{As cartas de João e seu lugar na literatura joanina}

As cartas de João, em número de três, formam um conjunto desigual no que toca à extensão desses escritos: a Primeira Carta, a mais longa, tem cinco capítulos, enquanto as outras duas têm apenas um, como também no que toca ao gênero literário: a Segunda e a Terceira são características do gênero literário epistolar, enquanto que a Primeira corresponde mais ao gênero homilético, ainda que se tratando de uma homilia escrita. ${ }^{3}$ Nem sempre essas

\footnotetext{
${ }^{3}$ Para J. Zumstein, embora, na Primeira Carta de João, falte o formulário epistolar clássico, nesse escrito "a intenção profunda do gênero epistolar é realizada: compensar a ausência do
} 
cartas circularam conjuntamente. A Primeira Carta de João é conhecida dos cristãos do Oriente e do Ocidente desde o início do cristianismo, enquanto que a Segunda e a Terceira eram conhecidas apenas pelos cristãos do Ocidente, chegando aos cristãos do Oriente somente a partir dos séculos III e IV. ${ }^{4}$

Por outro lado, vocabulário, estilo e teologia são tão próximos nessas três cartas que dificilmente se possa argumentar que não provenham de um mesmo autor, o presbítero que se apresenta no início da Segunda e da Terceira Carta (2Jo 1; 3Jo 1), ou, ao menos, de um círculo de autores muito próximos entre si. Um elemento que une essas cartas é o uso da palavra anticristo, presente na Primeira Carta e na Segunda Carta. Aliás, na Segunda Carta aparece várias vezes como um termo médio. São poucas as semelhanças entre a Primeira e a Terceira, mas elas são frequentes entre a Terceira e a Segunda e entre a Segunda e a Primeira. ${ }^{5}$

De acordo com R. E. Brown, o Evangelho segundo João e as três cartas de João provêm de um mesmo ambiente que ele chama de a comunidade do Discípulo Amado, cada um desses escritos provindo de um momento distinto dessa comunidade, com características e desafios próprios. ${ }^{6}$ Quanto às cartas, seria possível considerar que sua disposição no Novo Testamento não reflete sua sequência cronológica. A Terceira Carta de João, com seu testemunho a favor da acolhida dos de fora, de modo especial, daqueles que fazem parte da equipe missionária do presbítero autor da Carta, seria a Carta mais antiga. A Segunda Carta de João, ao contrário, é uma advertência contra certos pregadores itinerantes que têm espalhado uma falsa doutrina, chamados de enganadores e anticristos, e seria posterior à Terceira Carta. A Primeira Carta, por sua vez, explicita esse tema e tem as características de um discurso de adeus, sendo a última dentre as três. ${ }^{7}$

A comparação das três cartas com o Evangelho segundo João revelam muitas semelhanças e umas tantas diferenças. A diferença fundamental está em que o conflito subjacente ao Evangelho segundo João é aquele com as

autor junto aos destinatários com uma mensagem escrita, a qual faz eco a uma situação histórica determinada". Ele conclui que o gênero literário desse escrito é o de uma carta parenética. ZUMSTEIN, J., As epístolas joaninas, p. 473-475.

${ }^{4}$ MALZONI, C. V., Las cartas de Juan, p. 1149. A Segunda e a Terceira cartas de João estão, portanto, no grupo de escritos do Novo Testamento conhecidos, desde Eusébio de Cesareia, como antilegomenoi, ou seja, disputados. MANNUCCI, V., Bíblia, palavra de Deus, p. 238-239. ${ }^{5}$ BROWN, R. E., A comunidade do discípulo amado, p. 97-98. MALZONI, C. V., Las cartas de Juan, p. 1149-1150.

${ }^{6}$ BROWN, R. E., A comunidade do discípulo amado, p. 98-101.

${ }^{7}$ MALZONI, C. V., Las cartas de Juan, p. 1152. 
autoridades da sinagoga, da qual os membros da comunidade joanina foram expulsos (Jo 9,22; 12,42-43; 16,2). Já o conflito subjacente às cartas é sempre intraeclesial: com aqueles que não querem receber os pregadores itinerantes (Terceira), com aqueles que chegam trazendo outro ensinamento (Segunda), com aqueles que se foram da comunidade após a cisão (Primeira). Isso posto, vêm as semelhanças. Elas se mostram no vocabulário e no estilo muito próximos, bem como na perspectiva teológica bem parecida desses escritos, de modo que é possível utilizar textos de uns para compreender textos de outros com toda legitimidade. ${ }^{8}$

Do estilo muito próximo desse conjunto de escritos, pode-se dar como exemplo a argumentação que se desenvolve pelo jogo de antíteses, das quais as mais básicas são: vida e morte, luz e trevas, amor e ódio, verdade e mentira, com seus correspondentes em formas verbais e em adjetivos, incluindo alguns advérbios. Do vocabulário muito próximo, pode-se dar como exemplo o uso do verbo ménō, testemunhar. Das 76 atestações desse verbo no Novo Testamento, 46 encontram-se na literatura joanina, assim distribuídas: Evangelho segundo João: 33; Primeira Carta de João: 6; Terceira Carta de João: 4. Quanto à perspectiva teológica, pode-se destacar a tensão entre a escatologia presente e futura, típica do Evangelho segundo João, que toma outra direção na Primeira Carta de João. ${ }^{9}$ A palavra hốra, hora, frequente no Evangelho segundo João com 26 atestações, indicando não exclusivamente, mas majoritariamente, a páscoa de Jesus, conta com apenas 2 atestações na Primeira Carta de João, indicando a presença dos anticristos que saíram pelo mundo (1 Jo 2,18).

\section{A palavra anticristo: atestações e significado}

Se a hipótese levantada acima estiver correta, quanto à cronologia das cartas, então a primeira ocorrência da palavra anticristo é aquela que se encontra na Segunda Carta de João. Essa Carta é composta de quatro partes distintas: entre a saudação inicial (2Jo 1-3) e a saudação final (2Jo 12-13), há duas partes centrais, uma em torno da palavra entolé, mandamento (2Jo 4-6), outra em torno da palavra didaché, ensinamento (2Jo 7-11). É nessa perícope sobre o ensinamento que se encontra a palavra anticristo, em 2Jo 7: "Muitos

\footnotetext{
${ }^{8}$ BROWN, R. E., A comunidade do discípulo amado, p. 101; ZUMSTEIN, J., As epístolas joaninas, p. 474.477-479.

${ }^{9}$ BROWN, R. E., Primeira epístola (carta) de João, p. 526; ZUMSTEIN, J., As epístolas joaninas, p. 484.
} 
enganadores saíram pelo mundo, aqueles que não confessam Jesus Cristo vindo na carne. Esse é o enganador e o anticristo". ${ }^{10}$

$\mathrm{O}$ anticristo é também chamado de plános, enganador. Em 2Jo 7, estão as duas únicas atestações dessa palavra na literatura joanina, que ocorre também em Mt 27,63; 2Cor 6,8; 1Tm 4,1. Essa última atestação merece ser mencionada, dada a semelhança com 2Jo 7. Eis o texto de 1Tm 4,1: "Mas o Espírito expressamente diz que nos últimos tempos alguns abandonarão a fé, dando atenção a espíritos enganadores e a ensinamentos de demônios". Essa semelhança é um indício de que esses dois escritos podem provir de uma mesma época, quando a igreja estava às voltas com tais enganadores.

Se o adjetivo plános, enganador, ocorre apenas em $2 \mathrm{~J} o 7$ nas cartas joaninas, a configuração muda quanto se leva em consideração o substantivo congênito: plánē, engano, que ocorre em 1Jo 4,6, e o verbo planáō, enganar, presente em Jo 7,12.47; 1Jo 1,8; 2,26; 3,7. Nessas atestações, trata-se de distinguir entre o espírito da verdade e o espírito do engano $\left(1 \mathrm{Jo}_{0} 4,6\right)$ e de não enganar-se a si mesmo afirmando que não se tem pecado (1Jo 1,8$)$. Também de não se deixar desviar por aqueles que querem enganar (1Jo 2,26; 3,7). Em 1Jo 3,7, a enganação tem a ver com a justiça: "Filhinhos, que ninguém vos engane. Quem pratica a justiça é justo, como também ele é justo". A atitude do anticristo, portanto, como vem descrita em 2Jo 7, tem a ver com toda essa enganação.

A atitude dos enganadores e anticristos também tem a ver com o não confessar Jesus Cristo vindo na carne, ainda conforme 2Jo 7. Para confessar, está o verbo homologéō, presente com 10 atestações na literatura joanina (Jo 1,20.20; 9,22; 12,42; 1Jo 1,9; 2,23; 4,2.3.15; 2Jo 7). Algumas dessas atestações na Primeira Carta de João também ocorrem em passagens nas quais se trata de advertências quanto às atitudes dos anticristos, que em breve serão visitadas. Resta a questão da expressão "Jesus Cristo vindo na carne", na qual o acento tanto pode ser colocado em Jesus Cristo, como em vindo na carne. A diferença é sutil. ${ }^{11}$

\footnotetext{
${ }^{10}$ Os textos bíblicos foram tomados predominantemente de BÍBLIA: Novo Testamento. Em alguns casos uma tradução mais literal foi proposta a partir de o NOVO TESTAMENTO grego. ${ }^{11}$ R. E. Brown poderia ser situado entre os autores para os quais a negação é quanto à encarnação, muito embora afirme que "[o]s separatistas negavam a importância total de Jesus como o Cristo, o Filho de Deus": BROWN, R. E., Primeira epístola (carta) de João, p. 527. Já para S. van Tilborg a negação é quanto à manifestação de Deus em Jesus. Comentando 1Jo 1,2; 3,5.8 afirma que esses textos: "não tratam da encarnação do Filho de Deus no homem Jesus, mas da confissão de que, em Jesus, Deus se revela a nós". Ele próprio chama esses dois modelos de compreensão de modelo da encarnação e modelo da manifestação: TILBORG, S. van., As cartas de João, p. 182.
} 
$\mathrm{Na}$ Primeira Carta de João, são quatro atestações da palavra anticristo e as duas primeiras vão juntas, em 1 Jo 2,18, versículo que deve ser lido com o versículo seguinte:

Filhos, é chegada a última hora. Ouvistes que um anticristo estava para chegar e eis que agora muitos anticristos estão surgindo. Daí, concluímos que é chegada a última hora. Eles saíram de nosso meio, mas não eram dos nossos; se fossem dos nossos, teriam permanecido conosco, mas foi para que se tornasse manifesto que nem todos são dos nossos (1Jo 2,18-19).

"Um anticristo ... muitos anticristos". O uso da palavra no plural faz pensar que o autor da Carta se refere a determinadas atitudes assumidas por um grupo, do que propriamente a uma pessoa, mas resta o uso no singular que parece indicar alguém em específico. Quanto ao grupo, esse seria o daqueles mencionados logo a seguir: o daqueles que deixaram a comunidade. Aliás, 1 Jo 2,19 é um versículo chave para a identificação do contexto em que a Primeira Carta de João foi escrita: após um conflito que cindiu a comunidade, e sua finalidade: confirmar aqueles que permaneceram. ${ }^{12}$

$\mathrm{O}$ autor da Carta faz a ligação entre o surgimento dos anticristos e a chegada da última hora. Enquanto expressão, é única no Novo Testamento e indica a chegada de um momento decisivo, no qual ainda é possível uma tomada de posição, que precede imediatamente o momento final. Um anúncio semelhante já tinha aparecido em 1Jo 2,8, quando o autor escrevia que "as trevas passam e a luz verdadeira já brilha”. Quanto ao momento final, ele é o da parusia e da manifestação do Filho de Deus (1Jo 2,28), que será também o da manifestação dos filhos de Deus (1Jo 3,2). Assim, o surgimento dos anticristos indica, segundo o autor da Carta, que o fim está muito próximo.

A atestação seguinte encontra-se em 1 Jo 2,22: "Quem é o mentiroso senão aquele que nega que Jesus é o Cristo? Este é o anticristo: aquele que nega o Pai e o Filho". Em relação às atestações anteriores, há três novos elementos. O primeiro é que o anticristo é mentiroso. $\mathrm{O}$ adjetivo pseútēs, mentiroso, não apenas entra no vocabulário típico da literatura joanina como está no campo semântico de uma das antíteses básicas dessa literatura: aquela da verdade versus a mentira. No Evangelho segundo João, esse adjetivo ocorre em Jo 8,44.55; na Primeira Carta de João, em 1Jo 1,10; 2,4.22; 4,20; 5,10. Todas essas atestações encontram-se

\footnotetext{
${ }^{12} \mathrm{R}$. E. Brown sugere, a partir de $1 \mathrm{Jo} 4,5$, que o grupo dos que se separaram pode ter sido maior do que o dos que ficaram: BROWN, R. E., A comunidade do discípulo amado, p. 108.
} 
em passagens polêmicas, sendo a mais forte dentre elas Jo 8,44: "Vós sois do diabo, vosso pai, e os desejos de vosso pai quereis fazer. Ele foi homicida desde o princípio, e não se manteve na verdade porque nele não há verdade. Quando fala a mentira, fala do que lhe é próprio, porque é mentiroso e pai da mentira". O segundo elemento novo é o uso do verbo arnéomai, negar. No Evangelho segundo João, são quatro atestações, dentre as quais Jo 1,20, versículo no qual também aparece o verbo homologéo, confessar, visto a pouco. Os dois verbos são usados a propósito de João Batista: "Ele confessou e não negou. Confessou: 'Eu não sou o Cristo"'. O terceiro elemento novo é a menção do Pai e do Filho. A primeira parte do versículo: "Quem é o mentiroso senão aquele que nega que Jesus é o Cristo?" (1Jo 2,22a) pode ser colocado em paralelo com 2Jo 7a-b: "Muitos enganadores saíram pelo mundo, aqueles que não confessam Jesus Cristo vindo na carne". Fica faltando, contudo, a referência a "vindo na carne", o que, indiretamente, poderia reforçar a interpretação de que, em 2Jo 7, o acento está em não confessar Jesus Cristo. Já a segunda parte do versículo: "Este é o anticristo: aquele que nega o Pai e o Filho" (1Jo 2,22b), mostra que negar que Jesus é o Cristo significa também negar o Pai e o Filho, e a relação que existe entre o Pai e o Filho, tantas vezes colocada em evidência no Evangelho segundo João, e o caminho de salvação escolhido pelo Pai, que envia seu Filho, que é Jesus Cristo.

A última atestação da palavra anticristo na Primeira Carta de João está em 1Jo 4,3, mas é necessário colocá-la em seu contexto de 1Jo 4,1-3, onde aparecem vários elementos que ajudam a compreendê-la:

Amados, não creiais em qualquer espírito, mas examinai se os espíritos são de Deus, porque muitos falsos profetas saíram pelo mundo. Nisto reconhecereis o Espírito de Deus: todo espírito que confessa Jesus Cristo vindo na carne é de Deus. Mas todo espírito que não confessa Jesus não é de Deus, e esse é o espírito do anticristo, a respeito do qual ouvistes que vem, e agora já está no mundo.

O contexto é claramente o da profecia, ou ainda, o de uma advertência contra as falsas profecias e, mais especificamente, contra os ensinamentos de falsos profetas. Em grego, é uma só palavra: pseudoprofêtai, falsos profetas, que vem se juntar a plánoi, enganadores, como termos que caracterizam a postura de anticristo. A comparação de 1Jo 4,1 com 2Jo 7 mostra que falsos profetas e enganadores são termos intercambiáveis: em 1Jo 4,1 são muitos falsos profetas que saíram pelo mundo; em 2Jo 7, são muitos enganadores que saíram pelo mundo. Há ainda a palavra pseútēs, mentiroso, que caracteriza o anticristo em 1Jo 2,22. 
As semelhanças entre 1Jo 4,1-3 e 2Jo 7 também estão na expressão "confessar Jesus Cristo vindo na carne". Tanto quanto para 2Jo 7, também para 1 Jo 4,1-3 valem as duas possibilidades de interpretação: a de que o acento esteja em "Jesus Cristo" ou em "vindo na carne", muito embora a diferença entre essas duas interpretações não sejam grandes, ao menos nesse contexto. A presença do anticristo no mundo é outro elemento que une esses versículos. A palavra kósmos, mundo, também é típica da literatura joanina, sendo usada majoritariamente, mas não exclusivamente, com um viés pejorativo, significando toda a realidade contrária à manifestação do Filho de Deus e, portanto, hostil aos que creem.

Também há semelhanças entre 1Jo 4,3 e 1Jo 2,18: o uso da palavra anticristo no singular e a informação de que ele é alguém de quem já se tinha ouvido falar.

Finalizadas as atestações da palavra anticristo nas cartas joaninas, cabe uma síntese do que essas atestações apresentaram. Primeiramente, das cinco ocorrências, quatro estão no singular e uma no plural, que é uma a atestação em 1Jo 2,18c. As atestações de 1Jo 2,18b e 1Jo 4,3 parecem indicar a figura de um anticristo, cuja vinda já tinha sido anunciada. As demais, ainda que estejam no singular, parecem indicar mais uma atitude, de negação de Jesus Cristo (1 Jo 2,22 ) ou de Jesus Cristo vindo na carne (2Jo 7) do que propriamente alguém em particular. Há outras palavras que também caracterizam o anticristo, usadas ora no singular, ora no plural: mentiroso (1Jo 2,22), falsos profetas (1 Jo 4,1), enganadores (2Jo 7). A ligação entre 1Jo 2,22 e Jo 8,44, torna a acusação de mentiroso muito forte, pois a mentira e o homicídio são próprias do diabo.

Os verbos que aparecem na caracterização do anticristo ou anticristos são, primeiramente, confessar e negar: confessar Jesus Cristo vindo na carne ou negar Jesus Cristo vindo na carne, o que também significa negar o Pai e o Filho. Tal negação significa não compreender que o projeto salvífico do Pai passa pela encarnação do Filho: Jesus Cristo. Significa buscar outro caminho de salvação, ou diminuir o valor salvífico da manifestação do amor de Deus que enviou seu Filho ao mundo, ou não compreender que a carne, ou seja, a existência humana vista a partir de sua fragilidade, está no âmbito da salvação, desenraizando a experiência salvífica de seus compromissos com o cotidiano existencial. Vale lembrar que a Primeira Carta de João, no Novo Testamento "é o escrito que mais estabelece uma relação entre fé e amor, entre professar que Jesus é o Cristo e o agir cristão". ${ }^{13}$

${ }^{13}$ SILVANO, Z., Primeira Carta de João, p. 9. 
Também é importante o verbo sair, usado enquanto sair para e sair de. $\mathrm{Na}$ expressão sair para estão muitos enganadores (2Jo 7) e muitos falsos profetas (1Jo 4,1) que saíram para o mundo. O mundo é, assim, o âmbito onde o anticristo, os anticristos se situam. Na expressão sair de estão aqueles que "saíram de nosso meio" (1Jo 2,19). Foram, pois, para o âmbito do mundo, do anticristo.

As atestações da palavra anticristo nas cartas joaninas, e, sobretudo, aquelas de 1 Jo 2,18, colocam a chegada do anticristo, o surgimento dos anticristos em perspectiva escatológica, como o evento da última hora, aquela decisiva, que antecede a parusia. Em continuidade com o Evangelho segundo João, o autor da Primeira Carta de João se refere à manifestação já acontecida do Filho Jesus, quando afirma: "E sabeis que ele se manifestou para tirar nossos pecados, e nele não há pecado" (1Jo 3,5). Ou ainda: "Para isto o Filho de Deus se manifestou: para destruir as obras do diabo" (1 Jo 3,8b). Paralelamente, em textos muito próximos uns dos outros, afirma a manifestação que ainda está por vir (1 Jo 2,28; 3,2), à qual o surgimento dos anticristos indica a iminência. ${ }^{14}$

Essas são as atestações da palavra anticristo no Novo Testamento. É o momento de passar para seu significado nos dicionários. O Léxico gregoportuguês do Novo Testamento baseado em domínios semânticos, tradução do léxico em inglês de Johannes Louw e Eugene Nidda, apresenta para antíchristos o significado de "alguém que se opõe a Cristo, no sentido de usurpar a função de Cristo", e acrescenta que parece que o termo tenha se tornado "mais e mais equivalente a um nome próprio, como a personificação de tudo o que se opunha e era contrário à função e ao ministério de Cristo". ${ }^{15}$

J. P. Moulton e G. Milligan, em The Vocabulary of the Greek Testament citam Grimm que sugere que João cunhou a palavra anticristo. Por outro lado, o modo como a palavra é introduzida em 1Jo 2,18, leva a pensar que já era familiar para os leitores da Carta, podendo ter sido utilizada pelo autor em sua pregação anterior às cartas. Eles elencam três possibilidades básicas de significado: (a) um Cristo rival; (b) um opositor a Cristo; (c) um substituto para Cristo. O modelo para a construção da palavra pode ter sido antitheos. Em geral, a fórmula antí-x designa alguém ou algo que reivindica ser $x$, oposição a $x$, ou equivalência a $x{ }^{16}$

$\mathrm{O}$ dicionário A Greek-English Lexicon of the New Testament and other Early Christian Literature, de Walter Bauer, revisado por Frederick William

\footnotetext{
${ }^{14}$ Ver, a esse respeito, as reflexões de ZEMSTEIN, J., As epístolas joaninas, p. 484, e de SILVANO, Z., Primeira Carta de João, p. 17.

${ }^{15}$ LOUW, J.; NIDA, E., Léxico grego-português do Novo Testamento, p. 484.

${ }^{16}$ MOULTON, J. P.; MILligAN, G., The Vocabulary of the Greek Testament, p. 49.
} 
Danker, afirma que a palavra anticristo não é encontrada fora dos círculos cristãos, muito embora o conceito seja encontrado, citando a ocorrência do termo antitheos, na literatura grega. Quanto ao significado, traz "anticristo, adversário do Messias, a aparecer nos últimos dias", citando ocorrências do termo no Apocalipse de Esdras, no Apocalipse de Sidrac, no tratado Contra as Heresias, de Irineu de Lião, além daquelas nas cartas joaninas. Outros textos do Novo Testamento são citados nos quais a palavra não aparece, mas a ideia geral nela contida: 2 Ts $2,1-12$ e Ap $12-14 .^{17}$

Esse rol de significações da palavra anticristo nos dicionários, à primeira vista, parece extrapolar o itinerário percorrido anteriormente das atestações da palavra anticristo no Novo Testamento. De acordo com essas atestações o significado básico de anticristo é menos o de alguém que se opõe a Cristo, no sentido de usurpar sua função, e mais o de alguém que não professa que Jesus é o Cristo, com as implicações que essa profissão pressupõe. É possível que tenha havido ou um deslocamento no significado da palavra ou uma identificação da postura daqueles que saíram da comunidade, chamados de anticristos, com a postura de um anticristo.

Essa identificação é proposta por J. Ponthot, que escreve:

O termo grego antichristos só aparece nas epístolas joaninas: ali se faz menção à manifestação, prevista para o fim dos tempos, de um adversário decisivo do Cristo (1Jo 2,18a; 4,3) e, por outro lado, da antecipação dessa manifestação na ação de apóstatas que negam a fé cristológica (1Jo 2,18b.22; 2Jo 7). ${ }^{18}$

J. Ponthot nota que a tendência a personificar a oposição escatológica a Cristo está presente em outras passagens do Novo Testamento, e cita: 2Ts 2,38; Ap 13,1-8.11-18, como também Mc 13,5.22 e Mt 24,4.24. ${ }^{19}$

Nesse sentido, vale notar o texto de Irineu, citado no Léxico de Bauer e Danker, em Contra as Heresias, III,7,2:

\footnotetext{
${ }^{17}$ BAUER, W.; DANKER, F. W., A Greek-English Lexicon of the New Testament and Other Early Christian Literature, p. 91. As ocorrências da palavra anticristo no Apocalipse de Esdras e no Apocalipse de Sidrac são encontradas facilmente na internet; a referência em Irineu de Lião será dada abaixo. Apocalipse de Esdras: APOCALYPSES Apocryphae. A palavra anticristo está na página 29, linha 8. Apocalipse de Sidrac: APOCRYPHAL Anecdota. A palavra anticristo está na página 136, linha 33 .
}

${ }^{18}$ PONTHOT, J., Anticristo, p. 90.

${ }^{19}$ PONTHOT, J., Anticristo, p. 90. 
Ainda, na segunda carta aos Tessalonicenses, ao falar do Anticristo, Paulo diz: "Então se manifestará esse iníquo a quem o Senhor Jesus matará com o sopro da sua boca e destruirá com o esplendor de sua vinda, que se dará pela intervenção de Satã, com toda espécie de milagres, sinais e prodígios mentirosos". A ordem do pensamento é a seguinte: "Então se manifestará esse iníquo e a sua vinda se dará pela intervenção de Satã, com toda espécie de milagres, sinais e prodígios mentirosos e o Senhor Jesus o matará com o sopro da sua boca e destruirá com o esplendor de sua vinda". Com efeito, não será a vinda do Senhor que se dará pela intervenção de Satã, e sim a vinda do iníquo, que nós também chamamos Anticristo. ${ }^{20}$

Irineu identifica a figura de 2Ts 2,3 com o anticristo, de modo que chegou o momento de se perguntar sobre as possibilidades de identificação de outras figuras do Novo Testamento com o anticristo, os anticristos das cartas joaninas.

\section{Figuras semelhantes ao anticristo, aos anticristos das cartas joaninas nos demais escritos do Novo Testamento}

Já foi mencionado que a palavra plános, enganador, que caracteriza o(s) anticristo(s) em 2Jo 7, também ocorre, em contexto muito semelhante, em 1Tm 4,1. Outros paralelos serão agora levados em consideração, de modo especial, aqueles nos quais aparecem as palavras pseudocristo, pseudoprofeta, e a série de palavras e expressões presentes em 2Ts 2,1-12.

A palavra pseudóchristos, falso cristo, ocorre no Evangelho segundo Marcos, em um discurso direto de Jesus. Eis a atestação em seu contexto, em Mc 13,21-23: 'E, então, se alguém vos disser: 'Eis, aqui está o Cristo'. 'Eis, está ali'. Não acrediteis, pois surgirão falsos cristos e falsos profetas, e mostrarão sinais e prodígios para desviar, se possível, os eleitos. Vós, porém, estai atentos; eu vos predisse tudo". De imediato, chama a atenção as atestações paralelas de falsos cristos e falsos profetas. Quanto à palavra pseudóchristos, falso cristo, ela ocorre ainda uma vez no Novo Testamento, no Evangelho segundo Mateus: em Mt 24,24, passagem paralela a Mc 13,22. Aliás, o conjunto formado por Mt 24,23-25 segue, de muito perto, Mc 13,21-23, de modo que as observações feitas até aqui para esses versículos no Evangelho segundo Marcos, servem também para aqueles versículos no Evangelho segundo Mateus.

Quanto ao contexto mais amplo, Mc 13,21-23 insere-se no discurso

${ }^{20}$ IRENEU DE LIÃO, Contra as heresias, III,7,2. 
escatológico, o mais longo discurso direto de Jesus no Evangelho segundo Marcos. Esse discurso pode ser subdividido em sete temas: (1) as guerras, notícias de guerras, catástrofes naturais e situações de fome que anunciam o início do fim, simbolizado pelas "dores de parto", imagem que evoca o nascimento de uma nova vida (Mc 13,5-8); (2) as perseguições aos discípulos de Jesus e as divisões que atingirão as próprias famílias, diante das quais é preciso resistir até o fim (Mc 13,9-13); (3) a guerra na Judeia, que atinge Jerusalém e o Templo, provocando grande tribulação (Mc 13,14-20); (4) o surgimento de falsos cristos e falsos profetas, com sinais e prodígios ( $\mathrm{Mc}$ 13,21-23); (5) os sinais cósmicos e a vinda do Filho do Homem que enviará seus anjos para reunir os eleitos (Mc 13,24-27); (6) a parábola da figueira (Mc 13,28-31); (7) exortação à vigilância, pois ninguém sabe, senão o Pai, quando é o momento (kairós) em que essas coisas acontecerão (Mc 13,32-37). Do primeiro ao quinto tema, há como que uma sucessão de eventos, de modo que o surgimento de falsos cristos e falsos profetas é o que antecede imediatamente a manifestação do Filho do Homem. Nesse sentido, pode-se lembrar 1Jo 2,18 em que o surgimento de muitos anticristos assinala que é chegada a última hora.

A palavra pseudoprofêtés, falso profeta, ocorre onze vezes no Novo Testamento. Além de 1Jo 4,1; Mc 13,22 e Mt 24,24, textos já visitados, há oito ocorrências: Mt 7,15; 24,11; Lc 6,6; At 13,6; 2Pe 2,1; Ap 16,13; 19,20; 20,10. As que são de interesse, neste momento, são aquela da Segunda Carta de Pedro e aquelas do Apocalipse.

O livro do Apocalipse deu nome a seu gênero literário. Nele, a forma, de tão exuberante, chega a se sobrepor ao conteúdo. Isso posto, não significa que seja preciso despojar-se da forma para alcançar o conteúdo. O desafio está em encontrar o justo equilíbrio entre a beleza da forma e a severidade do conteúdo. Após a visão da batalha no céu (Ap 12,7), o dragão, expulso para a terra, vai guerrear contra os descendentes da mulher, "os que guardam os mandamentos de Deus e têm o testemunho de Jesus" (Ap 12,17). Aparece, então, um monstro que sobe do mar ao qual o dragão dá autoridade (Ap 13,1.4) e, depois, outro monstro que sobe da terra (Ap 13,11), posteriormente chamado de falso profeta (Ap 16,13). Ele desempenha o papel de promotor do culto do monstro que sobe do mar (Ap 13,11-12), imagem que remete ao culto oficial ao imperador romano. Ele será derrotado, assim como o dragão e o primeiro monstro (Ap 19,20; 20,10).

A Segunda Carta de Pedro é um escrito polêmico, dependente literariamente, em grande parte, da Carta de Judas. Seu tema teológico central é a insistência na parusia, com a consequente condenação dos falsos mestres 
que a negam. ${ }^{21}$ Nesse escrito, os falsos profetas estão ligados a falsos mestres e falsos ensinamentos, assim como os enganadores de $1 \mathrm{Tm} 4,1$. O texto de 2Pd 2,1 é assim: "Mas, como houve falsos profetas no meio do povo, assim também no meio de vós haverá falsos mestres que introduzirão maliciosamente doutrinas destrutivas, negando o Senhor que os resgatou e atraindo sobre si a destruição iminente". É preciso levar em consideração, contudo, que nem o ensinamento atribuído aos enganadores em $1 \mathrm{Tm} 4,3$, nem o comportamento atribuído aos falsos profetas em 2Pd 2,12-14, é atribuído aos enganadores e falsos profetas das cartas joaninas, senão o erro de não confessarem "Jesus Cristo vindo na carne" (2Jo 7, 1Jo 4,2).

A figura do falso profeta no livro do Apocalipse é extraeclesial; em linguagem joanina, seu âmbito de atuação é o mundo. Na Segunda Carta de Pedro, os falsos profetas atuam no âmbito intraeclesial. Em 1Jo 4,1, os falsos profetas saíram pelo mundo, eles atuam seja no mundo, seja na igreja, daí a necessidade do discernimento dos espíritos para que se identifique quais são de Deus e quais não são.

A Segunda Carta aos Tessalonicenses, na pesquisa atual sobre a teologia paulina, está colocada no grupo das cartas dêutero-paulinas, juntamente com as cartas aos Efésios e Colossenses. ${ }^{22}$ Essas cartas foram atribuídas a Paulo, mas dificilmente foram escritas pelo próprio Paulo, uma vez que refletem situações e problemáticas posteriores ao Apóstolo. Em 2Ts 2,1-12, há um texto com forte influência apocalíptica, no qual se busca explicar o porquê do atraso da parusia do Senhor Jesus Cristo. Assim escreve o autor desta Carta a respeito do que deve sobrevir antes que chegue o Dia do Senhor:

Que ninguém vos engane em nenhuma circunstância, porque primeiro deve vir a apostasia e ser revelado o homem da iniquidade, o filho da perdição, o adversário, aquele que se levanta contra tudo o que se chama Deus ou recebe culto, a fim de sentar-se no santuário de Deus, auto-proclamando-se Deus" (2Ts 2,3-4).

É impressionante o enfileiramento de expressões para caracterizar essa figura que está para se revelar, ou mesmo, que está se revelando: homem da iniquidade, filho da perdição e adversário. É uma figura de oposição absoluta a Deus precisamente porque quer ocupar o lugar de Deus. A referência ao

\footnotetext{
${ }^{21}$ SCHLOSSER, J., A segunda epístola de Pedro, p. 549.552.555-556.

${ }^{22}$ VOUGA, F., O corpus paulino, p. 184-186.
} 
poder político romano e ao culto ao imperador, ainda que não mencionados, é bastante clara. Não menos importante é a menção à apostasia: a negação da fé que atinge a comunidade em seu interior. $\mathrm{O}$ autor da Carta continua:

De fato, o mistério da iniquidade já está em ação. Somente é necessário que aquele que o detém até agora seja afastado. E então será revelado o iníquo, a quem o Senhor Jesus destruirá com o sopro de sua boca e aniquilará por ocasião da manifestação de sua vinda. A vinda do iníquo é segundo a atividade de Satanás, com todo poder e sinais e prodígios mentirosos, e com toda fraude de injustiça para aqueles que se perdem, uma vez que não acolheram o amor da verdade para que fossem salvos. E por isso, envialhes Deus uma inspiração de engano para que eles acreditem na mentira, a fim de que sejam julgados todos aqueles que não acreditaram na verdade, mas comprouveram-se na injustiça (2Ts 2,7-12).

A palavra parousia, traduzida no texto acima por vinda, refere-se seja ao Senhor Jesus (2Ts 2,8), seja ao iníquo (2Ts 2,9). Antes da parusia do Senhor Jesus, vem a parusia do iníquo, caracterizada por atos poderosos, sinais e prodígios, mas que são mentirosos. Aqueles que não acolhem o amor da verdade se deixam levar. Deus permite que acreditem na mentira, uma vez que se comprazem na injustiça. Nesses últimos versículos (2Ts 2,10-12), o autor da Carta pode estar novamente se referindo àqueles que caíram na apostasia.

$\mathrm{O}$ iníquo, mencionado em 2 Ts 2,9 , é aquele que Irineu, no texto acima, chama de Anticristo.

O confronto decisivo que antecede o fim, está presente em alguns desses textos, notadamente em 1Jo 2,18; Mc 13,22; Mt 24,24; 2Ts 2,1-12. Essa é a situação no Novo Testamento. O esquema de um confronto decisivo antes do fim também pode ser encontrado no Antigo Testamento, de modo especial, no livro de Daniel, em Dn 7-8, e em outros escritos intertestamentários, de cunho apocalíptico, dependentes de Daniel. É possível que esses escritos, por sua vez, tenham encontrado esse esquema em mitos babilônicos ou iranianos. ${ }^{23}$

\section{Conclusão}

Ao final desse percurso, é preciso voltar às atestações da palavra anticristo nas cartas joaninas, ou seja, voltar ao ponto de partida. A respeito

${ }^{23}$ PONTHOT, J., Anticristo, p. 90. 
dessas atestações mostrou-se necessário distinguir entre a figura do anticristo de 1Jo 2,18a, aquele a respeito do qual os interlocutores da Carta já tinham ouvido falar que estava para chegar, do uso que o autor da Carta faz da palavra no plural: anticristos, em 1 Jo 2,18b, ou acompanhada de outros termos no plural: enganadores e falsos profetas (2Jo 7; 1 Jo 4,3). A atestação em 1Jo 2,22 permanece ambígua, podendo alinhar-se tanto à figura do anticristo, uma vez que o termo está no singular, quanto aos anticristos, uma vez que é mentiroso e nega que Jesus é o Cristo.

A figura do anticristo (uso no singular) pode ser referir ao diabo: aquele que é mentiroso e pai da mentira, homicida desde o princípio (Jo 8,44; 1 Jo $3,15)$. Não é impossível que o autor da Primeira Carta de João tenha em mente alguma situação concreta em que o poder diabólico esteja se manifestando, como algum falso Messias que tenha aparecido em seu tempo, mas ele não dá pistas suficientes em sua Carta para que se possa afirmá-lo, contrariamente aos autores do Apocalipse e da Segunda Carta aos Tessalonicenses.

Ao chamar de anticristos aqueles que deixaram a comunidade, ele, expressamente, está afirmando que esses passaram a viver a partir de valores do anticristo: a falsidade, a mentira, a enganação, e o homicídio que se manifesta no ódio (1Jo 3,15). Diferentemente dos enganadores da Primeira Carta a Timóteo e dos falsos profetas da Segunda Carta de Pedro, os anticristos das cartas joaninas já não estão mais na comunidade, ainda que possam exercer alguma influência sobre ela.

Seria o caso de deixar de amá-los? Que responda o próprio o autor da Carta: "Nós sabemos que passamos da morte para a vida porque amamos os irmãos. Quem não ama permanece na morte" (1Jo 3,14).

\section{Referências bibliográficas}

APOCALYPSES Apocryphae: Mosi, Esdrae, Pauli, Iohannis, item Mariae Dormitio. Additis Evangeliorum et Actuum Apocryphorum Supplementis. Edidit C. Tischendorf. Lipsiae: Hermenn Mendelssohn, 1866. Disponível em: $<$ https://archive.org/details/apocalypsesapocr02tiscuoft/page/n5>. Acesso em: 21 out. 2019.

APOCRYPHAL Anedocta: a Collection of Thirteen Apocryphal Books and Fragments. Now first edited from manuscripts by M. R. James. Cambridge: The University Press, 1893. Disponível em: <https:/archive.org/details/ apocryphaanecdot00jame/page/n7>. Acesso em: 21 out. 2019. 
BAUER, W.; DANKER, F. W. A Greek-English Lexicon of the New Testament and other early Christian Literature. 3.ed. Chicago / London: Chicago University Press, 2000.

BÍBLIA: Novo Testamento. $1^{\mathrm{a}}$ reimpr. São Paulo: Paulinas, 2016.

BROWN, R. E. A comunidade do discípulo amado. São Paulo: Paulus, 1999. (Nova coleção bíblica).

BROWN, R. E. Primeira epístola (carta) de João. In: BROWN, R. E. Introdução ao Novo Testamento. São Paulo: Paulinas, 2004. p. 519-533. (Coleção Bíblia e história)

INSTITUTE FOR NEW TESTAMENT TEXTUAL RESEARCH AND THE COMPUTER CENTER OF MÜNSTER UNIVERSITY. Concordance to the Novum Testamentum Graece of Nestle-Aland, $\mathbf{2 6}^{\text {th }}$ edition, and to the Greek New Testament. 3.ed. Berlin: Walter de Gruyter, 1987.

IRENEU DE LIÃO. Contra as heresias: denúncia e refutação da falsa gnose. Introdução, notas e comentários H. Ribeiro. 2.ed. São Paulo: Paulus, 1995. (Coleção Patrística, 4).

LOUW, J. P.; NIDA, E. A. Léxico grego-português do Novo Testamento baseado em domínios semânticos. Barueri: Sociedade Bíblica do Brasil, 2013.

MALZONI, C. V. Las cartas de Juan. In: LEVORATTI, A. J.(Dir.). Comentario bíblico latino-americano. Estella: Verbo Divino, 2003. p. 1149-1172.

MALZONI, C. V.; COMISSÃO EPISCOPAL PASTORAL PARA A ANIMAÇÃO BÍBLICA. Mês da Bíblia 2019: para que n'Ele nossos povos tenham vida. Brasília: Edições CNBB, 2019.

MANNUCCI, V. Bíblia, palavra de Deus: curso de introdução à Sagrada Escritura. 4.ed. São Paulo: Paulus, 2008. (Biblioteca de estudos bíblicos).

MOULTON, J. H.; MILLIGAN, G. The Vocabulary of the Greek Testament. Illustrated from the Papyri and Other Non-literary Sources. London: Hodder and Stoughton, 1914-1929.

NOVO TESTAMENTO grego. Com introdução em português e dicionário grego-português. 4.ed. revisada. Barueri: Deutsche Bibelgesellschaft / Sociedade Bíblica do Brasil, 2009.

PONTHOT, J. Anticristo. In: INFORMÁTICA E BÍBLIA; ABADIA DE 
MAREDSOUS. Dicionário enciclopédico da Bíblia. São Paulo: Loyola / Paulus / Paulinas, 2013. p. 90-91.

SCHLOSSER, J. A segunda epístola de Pedro. In: MARGUERAT, D. (Org.). Novo Testamento: história, escritura e teologia. 3.ed. São Paulo: Loyola, 2015. p. 549-558.

SILVANO, Z. Primeira carta de João: crer em Jesus Cristo e amar uns aos outros. São Paulo: Paulinas, 2019. (Coleção pão da palavra).

TILBORG, S. van. As cartas de João. In: THEVISSEN, G.; KAHMANN, J. J. A.; DEHANDSCHUTTER, B. As cartas de Pedro, João e Judas. São Paulo: Loyola, 1999. p. 179-291. (Bíblica Loyola).

VOUGA, F. O corpus paulino. In: MARGUERAT, D. (Org.). Novo Testamento: história, escritura e teologia. 3.ed. São Paulo: Loyola, 2015. p. 181-203.

ZUMSTEIN, J. As epístolas paulinas. In: MARGUERAT, D. (Org.). Novo Testamento: história, escritura e teologia. Tradução M. Oliva. 3.ed. São Paulo: Loyola, 2015. p. 471-492.

Cláudio Vianney Malzoni Doutor em exegese bíblica pela Escola Bíblica e Arqueológica Francesa de Jerusalém Docente e pesquisador na Universidade Católica de Pernambuco Recife/ PE - Brasil E-mail: cvmalzoni@hotmail.com

Recebido em: 22/10/19 Aprovado em: 08/11/19 